\title{
PENGARUH MODEL PEMBELAJARAN PROBLEM BASED LEARNING TERHADAP HASIL BELAJAR PENDIDIKAN PANCASILA DAN KEWARGANEGARAAN SISWA KELAS V SDN PONDOK PINANG 05
}

\author{
Siti Asrifah*, Alrahmat Arif \\ Universitas Negeri Jakarta, Jakarta, Indonesia \\ *Email: sitiasrifah@gmail.com
}

Informasi Artikel Abstrak

Kata kunci:

Problem Based Learning

PPKn.

Sekolah Dasar

Diterima: $12-10-2020$

Disetujui: $20-10-2020$

Dipubikasikan: 26-10-2020
Penelitian ini meiliki tujuan untuk mengetahui pengaruh model pembelajaran Problem Based Learning (PBL) terhadap hasil belajar Pendidikan Pancasila dan Kewarganegaraan (PPKn) kelas V Sekolah Dasar Negeri. metode yang digunakan pada penelitian ini eksperimen dengan rancangan One-group pretest-postest. Adapun pola dari One-group pretest-postest. Hasil uji hipotesis menggunakan t-test diperoleh thitung $(16,39)>\operatorname{ttabel}(2,093)$, Dari hasil perhitungan effect size diperoleh sebesar 0,42. Sehingga dapat disimpulkan bahwa terdapat pengaruh penggunaan model problem based learnng terhadap hasil belajar pada pembelajaran Pendidikan Pancasila dan Kerawganegaaraan kelas V SDN Pondok pinang 05.

\section{PENDAHULUAN}

Pendidikan adalah sebuah proses dengan model-model tertentu sehingga orang memperoleh pengetahuan, pemahaman, dan cara bertingkah laku yang sesuai dengan kebutuhan. Tujuan pendidikan pada dasarnya adalah membentuk sumber daya manusia yang berkualitas, seperti yang disebutkan di dalam UUD 1945 pasal 31 ayat 3 bahwa pemerintah mengusahakan dan menyelenggarakan satu sistem pendidikan nasional, yang meningkatkan keimanan dan ketakwaan serta akhlak mulia dalam rangka mencerdaskan kehidupan bangsa, yang diatur dengan undang-undang. Hal ini juga disebutkan di dalam Undang-Undang Nomor: 20 Tahun 2003 Bab II Pasal 3 Pendidikan nasional berfungsi mengembangkan kemampuan dan membentuk watak serta peradaban bangsa yang bermartabat, bertujuan untuk berkembangnya potensi peserta didik agar menjadi manusia yang beriman dan bertaqwa kepada Tuhan Yang Maha Esa, berakhlak mulia, sehat, berilmu, cakap, kreatif, mandiri, dan menjadi warga negara yang demokratis serta bertanggung jawab. 
Untuk dapat mencapai tujuan pendidikan tersebut maka diperlukan adanya peningkatan mutu pendidikan. Hal yang dapat dilakukan untuk meningkatkan mutu pendidikan antara lain dengan meningkatkan kualitas guru, memperbaiki kurikulum, sistem pendidikan, bahkan proses kegiatan belajar mengajar di sekolah baik di dalam kelas maupun di luar kelas. Proses pembelajaran itu sendiri merupakan suatu proses interaksi antara siswa dengan guru yang meliputi unsur-unsur manusiawi, material, fasilitas, perlengkapan dan prosedur yang saling mempengaruhi dalam mencapai tujuan pembelajaran.

Dalam proses pembelajaran guru mempunyai peran yang sangat penting di dalam keberhasilan pencapaian tujuan pembelajaran. Guru tidak hanya dituntut untuk menguasai bidang studi yang akan diajarkan saja, tetapi juga harus menguasai dan mampu mengajarkan pengetahuan dan keterampilan pada siswa. Proses belajar mengajar hendaknya terjalin hubungan yang sifatnya mendidik dan mengembangkan. Guru kreatif, professional dan menyenangkan harus memiliki beberapa konsep dan cara untuk mendongkrak kualitas pembelajaran.

Pembelajaran akan berjalan dengan baik ketika guru memiliki tanggung jawab di dalam pembelajaran tersebut misalnya membuat inovasi dalam penggunaan model pembelajaran yang memungkinkan siswa bisa belajar secara maksimal dan mengembangkan kemampuan yang dimilikinya. Belajar pada dasarnya merupakan proses mental dan proses berpikir dengan memanfaatkan segala potensi yang dimiliki setiap individu secara optimal untuk memperoleh suatu perubahan tingkah laku secara keseluruhan, sebagai hasil pengalaman individu itu sendiri dalam interaksinya dengan lingkungan.

Dalam proses pembelajaran itulah terjadi proses transformasi ilmu pengetahuan serta nilai-nilai. Ketika proses pembelajaran berlangsung, terjadi interaksi antara guru dengan siswa yang memungkinkan bagi guru untuk dapat mengenali karakteristik serta potensi yang dimiliki siswa. Demikian pula sebaliknya, pada saat pembelajaran siswa memiliki kesempatan untuk mengembangkan potensi yang dimilikinya sehingga potensi tersebut dapat dioptimalkan. Oleh karena itu, pendidikan bukan lagi memberikan stimulus akan tetapi usaha mengembangkan potensi yang dimiliki. Pengetahuan itu tidak diberikan, akan tetapi dibangun oleh siswa (Sanjaya, 2009).

Untuk dapat mengenali dan mengembangkan potensi siswa tentunya dalam proses pembelajaran perlu bersifat aktif. Pembelajaran tidak lagi berpusat pada guru tetapi berpusat pada siswa dan guru hanya sebagai fasilitator serta pembimbing. Dengan demikian, siswa memiliki kesempatan yang luas untuk mengembangkan kemampuannya seperti mengemukakan pendapat, berpikir kritis, menyampaikan ide atau gagasan dan sebagainya. Belajar aktif sangat diperlukan oleh siswa untuk mendapatkan hasil yang maksimal. Ketika siswa pasif, atau hanya menerima dari guru ada kecenderungan untuk melupakan apa yang telah diberikan guru (Zaini, 2008). 
Dengan demikian, setiap pengetahuan yang dimiliki oleh siswa akan lebih bertahan lama karena kebenaran didapat oleh siswa sendiri. Akan tetapi kondisi yang terjadi saat ini kedudukan dan fungsi guru dalam kegiatan pembelajaran cenderung mendominasi dan aktivitas siswa sangat rendah. Hal ini sebagaimana pernyataan Cheong yang dikutip Majed Saleem Aziz dkk. Bahwa There is the weakness of the traditional science teaching method, under it that teacher-centred learning assumes that all learners take in recent material in a like speed and have like degree of knowledge in the topic being taught. A teacher guides the students and offers them new information. The focus of teaching is on the transmission of knowledge from the expert teacher to the novice learner(Aziz, Zain, Samsudin, \& Saleh, 2014).

Guru kurang memikirkan pengembangan proses pembelajaran, hanya terfokus di dalam mengejar materi dan disibukkan dengan hal-hal di luar pembelajaran. Dengan kondisi tersebut mengakibatkan siswa belajar hanya sekedar menghafal materi, pengetahuan yang didapat hanya dari guru saja, suasana belajar menjadi sangat membosankan dan kemampuan berpikir siswa pun tidak berkembang optimal sehingga hasil belajar pun kurang memuaskan.

Berdasarkan hasil lapangan yang telah dilakukan di SDN wilayah kelurahan Pondok Pinang pada tanggal 12 Agustus 2019, mata pelajaran Pendidikan Pancasila dan Kewarganegaraan (PPKn) terkesan sulit karena memiliki banyak teori yang harus difahami setiap siswa yang merupakan kompetensi pengetahuan kewarganegaraan (civic knowledge). Hal tersebut menyebabkan masih adanya anggapan bahwa mata pelajaran ini sebagai mata pelajaran yang membosankan dan jarang sekali siswa yang menjadikannya sebagai mata pelajaran favorit di sekolah. Padahal kompetensi kewarganegaraan bukan hanya civic knowledge saja. Menurut CCE (1994) dikenalkan tiga komponen kewarganegaraan, meliputi civic knowledge (pengetahuan kewargaan), civic skills (keterampilan kewargaan, meliputi cognitive skills dan participatory skills) dan civic dispositions (watak kewargaan) (Arif, 2016).

Untuk memperoleh hasil pembelajaran PPKn yang optimal perlu dilakukan dengan berbagai macam cara sehingga siswa dapat mengembangkan kompetensi civic knowledge, civic skills, dan civic dispositions.

Ada banyak factor yang mempengaruhi baik buruknya hasil belajar yang diperoleh siswa. Keberhasilan belajar peserta didik dipengaruhi oleh factor internal dan eksternal. Factor yang berasal dari dalam diri peserta didik dibagi menjadi dua yaitu factor psykologis dan fisiologis, sedangkan factor dari luar diri peserta didik meliputi lingkungan sekitar, guru, factor social, metode pembelajaran, dll (Daryanto dan Muljo, 2012).

Guru merupakan ujung tombak dalam pendidikan karena guru secara langsung berupaya mempengaruhi, mengembangkan dan membina kemampuan siswa agar mencapai tujuan pembelajaran yang sudah ditetapkan. Hal ini sesuai dalam kurikulum 2004 guru diberikan kebebasan untuk mengubah, memodifikasi bahkan membuat sendiri perencanaan pembelajaran yang sesuai dengan kondisi sekolah dan daerah (Majid, 2011). 
Salah faktor yang menentukan keberhasilan dalam pembelajaran PPKn adalah pemilihan model pembelajaran yang tepat. Banyaknya model pembelajaran yang dikembangkan para pakar tidaklah berarti bahwa guru menerapkan semua model pembelajaran untuk setiap pembelajaran karena tidak semua model cocok untuk setiap topik atau mata pelajaran.

Dari masalah-masalah yang dikemukakan di atas, perlu dicari model pembelajaran yang dapat melibatkan siswa secara aktif berpikir terutama pada mata pelajaran PPKn. Pembelajaran yang mengutamakan penguasaan materi yang harus berpusat pada siswa (focus on learners). Pembelajaran yang dapat melatih siswa memecahkan masalah akan memberikan pembelajaran dan pengalaman belajar yang relevan dan kontekstual dalam kehidupan nyata dan mengembangkan mental yang kaya dan kuat pada siswa. Guru perlu mencari model pembelajaran yang cocok untuk topik yang akan diajarkan sehingga pengetahuan dapat tersampaikan secara sistematis dan menyenangkan. Diantara model pembelajaran yang dapat digunakan untuk mengaktifkan siswa dalam pembelajaran PPKn di SD adalah Problem Based Learning (PBL).

PBL yaitu pembelajaran berbasis masalah dimana masalah yang dikaji secara nyata dekat dengan kehidupan siswa. Menurut Ratumanan PBL membantu siswa memperoleh informasi yang sudah jadi dalam benaknya dan menyusun pengetahuannya sendiri tentang dunia sosial dan sekitarnya (Trianto, 2011a). Siswa yang terlibat dalam Pembelajaran Berbasis Masalah memerlukan satu masalah untuk dipecahkan dan untuk siswa yang tidak berpengalaman, masalah-masalah akan paling efektif jika masalah tersebut konkret dan dekat dengan keseharian. Model pembelajaran PBL dirancang untuk melatih siswa berpikir kritis. Menurut Bruner bahwa jika siswa berusaha sendiri untuk mencari pemecahan masalah serta pengetahuan yang menyertainya maka akan menghasilkan pengetahuan yang benar-benar bermakna (Trianto, 2011a).

Ibrahim dan Nur mengatakan bahwa PBL dikembangkan untuk membantu siswa mengembangkan kemampuan berpikir, pemecahan masalah, dan keterampilan intelektual (Trianto, 2011a). Dalam model ini guru berperan sebagai penyaji masalah, mengadakan dialog, memberi fasilitas, memberikan dorongan yang dapat meningkatkan keterampilan intelektual peserta didik. Model ini tidak hanya melatih siswa untuk berpikir secara kritis tapi juga mengajak siswa untuk menganalisis nilai-nilai yang muncul dalam berbagai isu atau permasalahan yang diajukan.

SDN di Kelurahan Pondok Pinang sudah banyak yang memulai proses pembelajaran dengan menggunakan berbagai model pembelajaran, diawali dengan siswa baru pada jenjang kelas yang berbeda. Permasalahan yang dihadapi dalam proses pembelajaran saat ini adalah rendahnya kemandirian siswa, kurangnya efektivitas, terbatasnya persiapan materi, dan masih besarnya anggapan dalam masyarakat bahwa guru merupakan sumber utama dalam proses pembelajaran, sehingga sumber-sumber lain seperti perpustakaan, laboratorium, media massa, kurang menunjang sehingga kerja kelompok dengan teman jarang dilakukan. Bahkan sebagian di antara guru, mengajar dengan minimnya persiapan, keterbatasan penguasaan 
materi, penggunaan media dengan seadanya, pembelajaran dengan pendekatan yang kurang bervariasi, pemberian tugas yang kurang melatih kemandirian, dan metode evaluasi yang kurang terencana, sehingga proses pembelajaran terkesan asal dilakukan, akibatnya siswa kurang merespon dan apabila diberi kesempatan bertanya tidak bertanya, di saat yang sama ketika diberi pertanyaan, siswa tidak berusaha untuk menjawab.

Seiring dengan kenyataan itu, bahwa guru tidak menciptakan suasana yang memberi kesempatan kepada siswa seluas-luasnya untuk mencari, menyelesaikan masalah dengan menyampaikan pendapat dan bertanya, karena keterbatasan kemampuan guru. Permasalahan yang dihadapi lebih mengarah pada pendekatan pembelajaran yang kurang memberikan kesempatan pada siswa dalam mencari, berusaha dan memecahkan masalah dengan berfikir, berpendapat, serta bertanggungjawab. Maka patutlah untuk mempertimbangkan pernyataan Fosnot bahwa The traditional passive view of learning involves situations where material is delivered to students using a lecture-based format. In contrast, a more modern view of learning is constructivism, where students are expected to be active in the learning process by participating in discussion and/or collaborative activities" (Carpenter, 2006).

Faktor lain yang mempengaruhi baik buruknya hasil belajar siswa yaitu faktor yang berasal dari diri siswa (internal). Salah satu faktor internal yang mempengaruhi hasil belajar siswa adalah gaya belajar. Setiap siswa mempunyai kemampuan dalam menyerap dan memahami pembelajaran yang disampaikan oleh guru. Menurut Carol Ann Tomlinson, dkk (2003:129) “The term learning profile refers to students preferred mode of learning that can be affected by a numbr of factor including learning style". Guru perlu memerhatikan perbedaan yang ada pada peserta didik, hal ini merupakan salah satu cara guru dalam mendekatkan diri pada peserta didik (Hendriana, 2018).

Menurut Bobbi De Poter \& Mike Hernacki belajar dipengaruhi oleh modalitas belajar. Ia membedakan gaya belajar ke dalam tiga kelompok besar, yaitu gaya belajar visual, gaya belajar auditorial dan gaya belajar kinestetik (Hernacki, 2003). Dalam penelitian ini, akan dibatasi pada gaya belajar visual dan auditori. Gaya belajar visual adalah kecenderungan yang dimiliki siswa untuk menangkap dan mengolah informasi dengan mengandalkan indera penglihatannya. Sedangkan gaya belajar auditori adalah kecenderungansiswa dalam menangkap dan mengolah informasi dengan cara memanfaatkan indera pendengarannya.

Kedua gaya belajar yang dimiliki siswa tersebut mempengaruhi siswa dalam proses pembelajaran. Jika gaya belajar dikaitkan dengan model pembelajaran yang diterapkan guru, maka hendaknya model pembelajaran yang diterapkan guru dapat menfasilitasi kedua gaya belajar tersebut. Pada peneliti ini mencoba mengadakan ekperimen khusus dengan membandingkan pengaruh proses pembelajaran yang menggunakan model pembelajaran Problem Based Learning (PBL) dan model pembelajaran Ekspositori 
terhadap hasil belajar Pendidikan Pancasila dan Kewarganegaraan (PPKn) dengan memperhatikan gaya belajar siswa.

Berdasarkan uraian di atas, maka peneliti terdorong melakukan penelitian untuk mengetahui pengaruh model pembelajaran dan gaya belajar terhadap hasil belajar siswa dengan judul "Pengaruh Model Pembelajaran Problem Based Learning dan Gaya Belajar terhadap Hasil Belajar Pendidikan Pancasila dan Kewarganegaraan siswa Kelas V SDN Pondok Pinang 05”.

Berkaitan dengan penelitian sebelumnya oleh Evinna Cinda Hendriana menunjukkan bahwa terdapat pengaruh signifikan antara model pembelajaran Problem Based Learning dan gaya belajar visual dalam mempengaruhi hasil belajar Ilmu Pengetahuan Sosial (Hendriana, 2018).

Penelitian sebelumnya juga dilakukan oleh Prihma Sinta Utami, Abdul Gafur dengan judul penelitian Pengaruh Metode Pembelajaran Dan Gaya Belajar Siswa Terhadap Hasil Belajar IPS di SMP Negeri di Kota Yogyakarta. Hasil penelitian menunjukkan bahwa hasil belajar IPS dengan menggunakan metode TPS lebih tinggi dibandingkan metode PBL pada kelompok gaya belajar visual (Utami \& Gafur, 2015).

Keterbaruan penelitan ini, dari dua penelitian sebelumnya adalah dari segi usia yakni kelas $\mathrm{V}$ pada jenjang sekolah dasar. Sedangkan kedua penelitian sebelumnya dilakukan pada kelas IV jenjang sekolah dasar dan kelas VII jenjang sekolah menengah pertama. Selanjutnya, penelitian sebelumnya menggunakan metode Problem-Based Learning dan metode Think Pair Share. Sementara penelitian yang akan saya lakukan menggunakan model pembelajaran Problem-Based Learning dan model pembelajaran Ekspositori.

\section{METODE}

Metode dalam penelitian ini menggunakan metode eksperimen. adapun Populasi pada penelitian ini adalah kelas V Sekolah Dasar Negeri 24 SDN Pondok Pinang 05 yang berjumlah 40 siswa terdiri dari dua kelas yaitu kelas VA yang berjumlah 20 siswa dan VB yag berjumlah 20 siswa. Sampel dalam penelitian ini adalah kelas eksperimen VB yang berjumlah 20 orang, yang terdiri dari 12 orang laki-laki dan 8 orang perempuan. Penentuan kelas dilakukannya penelitian dengan pemilihan acak yaitu melalui pengundian. Teknik pengumpulan data menggunakan teknik pengukuran dan alat pengumpulan datanya berupa tes soal pilihan ganda yang berjumlah 45 soal. Dalam prosedur perlakukan dengan tiga tahapan, pertama tahap persiapan, kedua tahap pelaksanaan, ketiga tahap pengolahan data.

\section{HASIL DAN PEMBAHASAN}

Penelitian ini dilaksanakan pada satu kelas yaitu VB (eksperimen). Treatmen dilakukan pada kelas eksperimen dengan studi kasus konteks dunia nyata kehidupan siswa sesuai dengan materi pelajaran. Sebelum diberikan pembelajaran materi yang diajarkan, maka kelas terlebih dahulu diberi pretest dan post-test dengan soal 
yang sama. Tujuan dari pretest adalah untuk mengetahui kesetaraan kemampuan kedua kelas. Skor pre-test dan post-test kelas eksperimen adalah tabel 1 berikut ini:

Tabel 1 Distribusi Frekuensi Kelas Eksperimen

\begin{tabular}{cccccc}
\hline \multicolumn{3}{c}{$\begin{array}{c}\text { Hasil Pre-test Kelas } \\
\text { Eksperimen }\end{array}$} & \multicolumn{3}{c}{$\begin{array}{c}\text { Hasil Post-test Kelas } \\
\text { Eksperimen }\end{array}$} \\
\hline No & Nilai & Frekuensi & No & Nilai & Frekuensi \\
\hline 1 & $40-44$ & 2 & 1 & $64-67$ & 1 \\
\hline 2 & $45-49$ & 2 & 2 & $68-71$ & 1 \\
\hline 3 & $50-54$ & 3 & 3 & $72-75$ & 3 \\
\hline 4 & $55-59$ & 7 & 4 & $76-79$ & 8 \\
\hline 5 & $60-64$ & 4 & 5 & $80-83$ & 4 \\
\hline 6 & $65-69$ & 2 & 6 & $84-87$ & 3 \\
\hline & Jumlah & 20 & & Jumlah & 20 \\
\hline & Rata-rata & 55,75 & & Rata-rata & 77,90 \\
\hline
\end{tabular}

Berdasarkan tabel 1 terlihat adanya perbedaan skor rata-rata hasil belajar siswa pada pre-test dan posttest. Skor rata-rata pre-test adalah 55,75 dan post-test adalah 77,90 selisih 22,15

Data hasil pre-test dan post-test siswa kemudian dianalisis dapat dilihat pada tabel 2 berikut ini :

Tabel 2 Hasil Perhitungan Pre-test dan Post-test

\begin{tabular}{lll}
\hline \multirow{2}{*}{ Keterangan } & \multicolumn{2}{l}{ Kelas Eksperimen } \\
\cline { 2 - 3 } & Pre-test & Post-test \\
\hline Rata-rata $\overline{(X)}$ & 55,75 & 77,90 \\
\hline Standar Deviasi & 7,23 & 5,17 \\
\hline Uji Normalitas $\left(x^{2}\right)$ & 2,6157 & 2,7627 \\
\hline & Pre-test & Post-test \\
\hline Uji Hipotesis $(t)$ & 16,36 & 2,093 \\
\hline Effect Size $(\mathrm{ES})$ & \multicolumn{2}{c}{0,42} \\
\hline
\end{tabular}

Berdasarkan tabel 2 hasil perhitungan Pre-test dan Post-test terlihat perbedaan yang signifikan antara sebelum dan sesudah diberi perlakuan dikelas eksperimen yang mana rata-rata Post-test kelas eksperimen lebih tinggi dibandingkan dengan Pre-test. Sedangkan standar deviasi kelas eksperimen menunjukan persebaran hasil belajar siswa lebih merata. Pada uji normalitas dikatakan normal. Uji hipotesis pada pre-test Ha ditolak sedangkan pada post-test Ha diterima. Perhitungan Effect size diperoleh 0,42 dengan katagori sedang. 
Penelitian ini dilakukan bertujuan untuk menganalisis seberapa besar pengaruh model problem based learning terhadap hasil belajar siswa dalam pembelajaran Pendidika Pancasila Kewarganegaraan di kelas V SDN Pondok pinang 05. Penelitian dilakukan di kelas V SDN Pondok pinang 05, dengan jumlah siswa 20 orang. Dari sampel tersebut maka didapat data berupa hasil pre-test dan post-test siswa, adapun data hasil pre-test dan data hasil post-test yang telah dilakukan, maka didapat data rata-rata pre-test atau hasil belajar siswa sebelum diberikan perlakuan dengan menggunakan model problem based learning yaitu sebesar 55,75 dan rata-rata hasil post-test siswa setelah diberikan perlakuan dengan menggunakan model problem based learning sebesar 77,90. Dari keterangan tersebut dapat diketahui bahwa hasil post-test siswa lebih besar dibandingkan dengan hasil pre-test.

Setelah dilakukan perhitungan rata-rata dan standar deviasi dari data pre-test dan post-test, selanjutnya dilakukan uji normalitas data dengan menggunakan uji chi kuadrat (X2) dan berdasarkan hasil perhitungan uji normalitas data pre-test dan post-test maka diperoleh hasil pre-test $x 2$ hitung $=2,6157$ kemudian dibandingkan dengan $x 2$ tabel dari daftar tabel Chi kuadrat dengan taraf signifikan $(\alpha)=0,05$ mka diperoleh $x 2$ tabel $=$ 7,815. Ini menunjukkan bahwa $x 2$ hitung $<x 2$ tabel atau $2,6157<7,815$, berarti signifikan. Maka dapat disimpulkan bahwa data hasil pre-test berdistribusi normal dan hasil perhitungan uji normalitas data post-test maka diperoleh hasil $x 2$ hitung $=2,7627$ kemudian dibandingkan dengan $x 2$ tabel dari daftar tabel Chi kuadrat dengan taraf signifikan $(\alpha)=0,05$ Maka diperoleh $x 2$ tabel $=7,815$. Ini menunjukkan bahwa $x 2$ hitung $<x 2$ tabel atau 2,7627<7,815, berarti signifikan. Maka dapat disimpulkan bahwa data hasil posttest berdistribusi normal.

Setelah dilakukan perhitungan data pre-test dan post-test yang berdistribusi normal, maka selanjutnya akan dilakukan analisis data uji t. Hasil uji hipotesis dengan menggunakan uji t diperoleh harga thitung 16,39, sedangkan ttabel dengan $\mathrm{db}=20-1=19$ dan taraf signifikan $(\alpha)=0,05$ adalah 2,093. karena thitung $>$ ttabel atau 16,39>2,093 berarti signifikan, jadi dapat disimpulkan bahwa Ha diterima atau disetujui dan Ho ditolak. Dari penjelasan perhitungan uji t tersebut, berarti terdapat pengaruh model problem based learning terhadap hasil belajar siswa dalam pembelajaran pendidikan Pancasila dan kewarganegraan di kelas V SDN Pondok pinang 05. Perubahan pemerolehan hasil belajar siswa pada pembelajaran pendidikan kewarganegara-an kelas V SDN Pondok pinang 05 tampak pada rata-rata pemerolehan hasil belajar siswa yang meningkat setelah diberikan perlakuan dengan menggunakan model problem based learning.

Untuk menganalisis besarnya pengaruh penerpan tipe problem based learning.terhadap hasil belajar siswa, dihitung dengan menggunakan rumus effect size. Diperoleh ES sebesar 0,42, karena ES $(0,42)>0,8$ maka kriteria nya adalah sedang. Berdasarkan perhitungan ES tersebut maka pembelajaran dengan menggunakan model problem based learning memberikan pengaruh yang sedang terhadap hasil belajar siswa pada mata pelajaran pendidikan kewarganegara-an kelas V SDN Pondok pinang 05. 
Tingkat keefektifan sebesar 0,42 dengan kategori sedang juga dipengaruhi oleh beberapa faktor. Faktorfaktor yang mempengaruhi hasil belajar siswa tersebut diantaranya adalah pada saat proses pembelajaran di kelas banyak siswa yang antusias dalam mengikuti pembelajaran dan siswa aktif dikelas dan saling berebut menjawab pertanyaan dari guru. Tetapi ada juga siswa yang masih ribut sendiri, berbicara sesama teman saaat proses pembelajaran berlangsung dan juga terdapat beberapa siswa yang memiliki intelegensi baik sehingga siswa tersebut mudah untuk belajar dan hasilnya pun baik. Sebaliknya siswa yang memiliki intelegensi rendah maka siswa tersebut mengalami kesulitan dalam belajar dan hasilnya pun rendah Keterbatasan peneliti dalam penelitian ini adalah kurang mengenalnya peneliti dengan siswa, selain itu keterbatasan waktu yang tersedia dalam melaksanakan kegiatan pembelajaran. Dengan keterbatasan waktu yang ada, kegiatan pembelajaran di kelas harus bisa dilaksanakan seefektif mungkin, sehingga pembelajaran yang berlangsung dapat berjalan dengan lancar.

\section{KESIMPULAN}

Berdasarkan dari hasil pembahasan di atas dapat kita simpulkan bahwa hasil belajar siswa kelas V pada kelas eksperimen Berdasarkan analisis uji $\mathrm{t}$ atau uji hipotesis diperoleh thitung16,39, sedangkan ttabel dengan $\mathrm{db}=20-1=19$ dan taraf signifikan $(\alpha)=0,05$ adalah 2,093. Karena thitung $>$ ttabel atau 16,39>2,093 berarti signifikan, jadi dapat disimpulkan bahwa Ha diterima atau disetujui dan Ho ditolak. Ini berarti terdapat pengaruh penerapan model problem based learning terhadap hasil belajar siswa pada pembelajaran Pendidikan Pancasila Kewarganegaraan kelas V SDN Pondok pinang 05. Pembelajaran dengan menerapkan model problem based learning memberikan kontribusi pengaruh yang sedang (dengan Effect Size sebesar 0,42 ) terhadap hasil belajar siswa dalam pembelajaran pendidikan kewarganegaraan di kelas $\mathrm{V}$ SDN Pondok pinang 05.

\section{DAFTAR PUSTAKA}

Undang-Undang Nomor: 20 Tahun 2003 Bab II Pasal 3 Pendidikan Nasional.

Abidin, Y. (2018). Desain Sistem Pembelajaran Dalam Konteles Kurikulum 2013 (P. R. Aditama, ed.). Bandung. Ali Mudlofir, E. F. R. (2016). Desain Pembelajaran Inovatif Dari Teori ke Praktik (P. R. Persada, ed.). Jakarta. Amir, T. (2013). Inovasi Pendidikan Melalui Problem Based Learning (P. M. Group, ed.). Jakarta.

Arends. (2009). Learning to Teach (P. Pelajar, ed.). Yogyakarta.

Arif, D. B. (2016). Pengembangan komponen kompetensi kewargaan dalam buku teks Pendidikan Kewarganegaraan SMP/MTs. Jurnal Civics: Media Kajian Kewarganegaraan, 13(1). https:// doi.org/10.21831/ civics.v13i1.11076

Arifin, Z. (2011). Penelitian Pendidikan (P. R. Rosdakarya, ed.). Bandung.

Arikunto, S. (2016). Prosedur Penelitian (R. Cipta, ed.).

Aunurrahman. (2011). Belajar dan Pembelajaran (Alfabeta, ed.). Bandung.

Aziz, M. S., Zain, A. N. M., Samsudin, M. A. Bin, \& Saleh, S. B. (2014). The Effects of Problem-Based 
Learning on Self-Directed Learning Skills among Physics Undergraduates. International Journal of Academic Research in Progressive Education and Development, 3(1). https://doi.org/10.6007/ijarped/v3-i1 /694.

Azwar, S. (2013). Reliabilitas dan Validitas (P. Pelajar, ed.). Yogyakarta.

Buchari, M. (1986). Dasar-dasar Kependidikan (Tarsito, ed.). Bandung.

Budimansyah. (2007). Penguatan Pendidikan Kewrganegaraan untuk Membangun Karakter Bangsa (W. A. Press, ed.). Bandung.

Carpenter, J. M. (2006). Effective teaching Methods for Large Classes. Journal of Family and Consumer Sciences Education, 24(2), 13-23. https://doi.org/10.1002/eat.20931.Psychometric

Chalish, M. (2011). Strategi Pembelajaran Berbasis Kompetensi (P. B. Aksara, ed.). Jakarta.

Cohen, R. J. \& Swerdlik, M. E. (2009). Psychology: Psychological testing and assessment: an introduction to tests and measurement (Edisi 7) (7th ed.; M.-H. C. Inc, ed.). New York.

Daryanto dan Muljo, R. (2012). Model Pembelajaran Inovatif(G. Media, ed.). Yogyakarta.

Dimyati dan Mudjiono. (2006). Belajar dan Pembelajaran (P. R. Cipta, ed.). Jakarta.

Djaali dan Pudji Muljono. (2008). Pengukuran dalam Bidang Pendidikan (P. Grasindo, ed.). Jakarta.

Erman Suherman, D. (2001). , Strategi Pembelajaran Matematika Kontemporer (U. P. Indonesia, ed.). Bandung.

Gandamana, A. (2013). Perbandingan Kompetensi Kewarganegaraan Dalam Kurikulum 2006 Dan Kurikulum 2013 Mata Pelajaran Pendidikan Kewarganegaraan Di Sekolah Dasar. Citizenship Competency, $\begin{array}{llllll}\text { Curriculum } 2006 & \text { (KTSP) } & \text { Curriculum } & \text { 2013, } & \text { 53(9), }\end{array}$ https://doi.org/10.1017/CBO9781107415324.004

Hamalik, O. (2006). Proses Belajar Mengajar (B. Aksara, ed.). Bandung.

Hamzah B. Uno dan Madain Muhammad. (2011). Belajar dengan Pendekatan Paikem (B. Aksara, ed.). Jakarta.

Haris, A. J. dan A. (2012). Evaluasi Pembelajaran (M. Presindo, ed.). Yogyakarta.

Hendriana, E. C. (2018). Pengaruh Model Pembelajaran Problem Based Learning Dan Gaya Belajar Auditorial Terhadap Hasil Belajar Ips Di Sekolah Dasar. JPDI (Jurnal Pendidikan Dasar Indonesia), 3(1), 1. https://doi.org/10.26737/jpdi.v3i1.484

Hernacki, B. D. dan M. (2003). Quantum Learning (Kaifa, ed.). Bandung.

Hudoyo, H. (2003). Kontemporer, Strategi Pembelajaran Matematika (UPI). BANDUNG.

JP. Chaplin. (1992). Psikologi Pengajaran (P. Jaya, ed.). Jakarta.

Kauchak, P. E. dan D. (2012). Strategi dan Model Pembelajaran. 242.

Kristiyani, S. dan T. (1991). Efektivitas Metode Problem - Based Learning dalam Pembelajaran Mata Kuliah Teori Psikologi Kepribadian II. Psikologi, 33(1), 17-32.

Majid, A. (2011). Perencanaan Pembelajaran Mengembangkan Standar Kompetensi Guru (PT. Rosda Karya, ed.). Jakarta.

Nata, A. (2009). Perspektif Islam tentang Strategi Pembelajaran (P. M. Group, ed.). Jakarta.

Nini Subini. (2012). Mengatasi Kesulitan Belajar Pada Anak (Javalitera, ed.). Yogyakarta.

Pangalila, T. (2017). PENINGKATAN CIVIC DISPOSITION SISWA MELALUI PEMBELAJARAN PENDIDIKAN KEWARGANEGARAAN (PKn). Jurnal Pendidikan Kewarganegaraan, Universitas Lambung Mangkurat, 7(1), 91-103.

Rahman, A. (2010). Pengembangan Perangkat Penilaian Hasil Belajar. 432. 
Risnawati, G. dan. (2013). Gaya Belajar Kajian Teoritik (P. Pelajar, ed.). Yogyakarta.

Rivai, N. S. dan A. (2013). Media Pengajaran (S. Baru, ed.). Bandung.

Rusman. (2016). Model-Model Pembelajaran; Mengembangkan Profesionalisme Guru (G. Persada, ed.). Jakarta.

S. Nasution. (2009). Berbagai pendekatan dalam Proses Belajar \& Mengajar (B. AKsara, ed.). Jakarta.

Sanjaya, W. (2006). Strategi Pembelajaran (K. P. M. Group, ed.). Jakarta.

Sanjaya, W. (2009). Strategi Pembelajaran Berorientasi Standar Proses Pendidikan (2009th ed.; Kencana Prenada Media, ed.). Retrieved from Kencana Prenada Media

Sanjaya, W. (2013). trategi Pembelajaran Berorientasi Standar Proses Pendidikan (P. M. Group, ed.). Jakarta.

Slameto. (2010). Belajar dan Faktor-faktor yang Mempengarubi (R. Cipta, ed.). Jakarta.

Soemantri. (2001). Menggagas Pembaharuan Pendidikan IPS (R. R. Karya, ed.). Bandung.

Subini, N. (2012). Rahasia Gaya Belajar Orang Besar (P. B. Kita, ed.). Yogyakarta.

Sudijono, A. (2012). Pengantar evaluasi pendidikan (P. R. Persada, ed.). Jakarta.

Sudjana. (2005). Metode Statistik No Title (Tarsito, ed.). Bandung.

Sugihartono. (2007a). Psikologi Pendidikan (U. Press, ed.). Yogyakarta.

Sugihartono, D. (2007b). Psikologi Pendidikan (U. Press, ed.). Yogyakarta.

Sugiyono. (2010). Statistik untuk Penelitian (Alfabeta, ed.). Bandung.

Sukadi. (2008). Progressive Leaming By Spirit (M. Publishing, ed.). Bandung.

Suprijono, A. (2013). Cooperative Learning (P. Belajar, ed.). Surabaya.

Supriyono, A. A. dan W. (2009). Psikologi Belajar (R. Cipta, ed.). Jakarta.

Suyadi. (2003). Strategi Pembelajaran Pendidikan Berkarakter (R. R. Karya, ed.). Bandung.

Tenaga, D. K. (2008). Strategi Pembelajaran dan Pemilihannya (Depdiknas, ed.). Jakarta.

Trianto. (2011a). Mendesain Model Pembelajaran Inovatif Progresif. 92.

Trianto. (2011b). Model Pembelajaran Terpadu. 22.

Turner, Long, B. and L. (1990). Civics: Citizens in Action (M. P. Company, ed.). Ohio.

Utami, P. S., \& Gafur, A. (2015). Pengaruh Metode Pembelajaran Dan Gaya Belajar Siswa Terhadap Hasil Belajar Ips Di Smp Negeri Di Kota Yogyakarta. Harmoni Sosial: Jurnal Pendidikan IPS, 2(1), 97-103. https:// doi.org/10.21831/hsjpi.v2i1.4622

Wena, M. (2009). Strategi Pembelajaran Inovatif Kontemporer; Suatu Kajian Konseptual (B. Aksara, ed.). Jakarta.

Winarno. (2019). Pembelajaran Pendidikan Kewarganegaraan Isi, Strategi, dan Penilaian (Bumi Aksara, ed.). Jakarta.

Winataputra. (2013). Pendidikan Kewarganegaraan dalam Perspektif Internasional; Konteks, Teori, dan Profil Pembelajaran (D. Asrimedia, ed.). Jakarta.

Zaini, H. (2008). Strategi Pembelajaran (I. Mandiri, ed.). Yogyakarta. 